\title{
Evaluation of Coffee Sludge as an Adsorbent of Cations and Chlorides from Mangrove Sediments
}

\author{
Larissa Montalvão Vieira ${ }^{1}$, Josimar Gurgel Fernandes ${ }^{2}$, Patrícia Ribeiro Santos ${ }^{2}$, Sergio Carvalho \\ de Paiva ${ }^{3}$, Galba Maria de Campos Takaki ${ }^{3}$ and Arminda Saconi Messias ${ }^{3 *}$ \\ ${ }^{1}$ Undergraduate student of the Environmental Engineering Course at the Catholic University of Pernambuco - UNICAP, Recife, \\ Pernambuco, Brazil \\ ${ }^{2}$ Agronomic Institute of Pernambuco - IPA, Recife, Pernambuco, Brazil \\ ${ }^{3}$ Teacher at the Catholic University of Pernambuco, Recife, Pernambuco, Brazil \\ *Corresponding author: Arminda Saconi Messias, Teacher at the Catholic University of Pernambuco, Recife, Pernambuco, \\ Brazil
}

\begin{abstract}
ARTICLE INFO
Received: 幽 August 04, 2020

Published: 幽 September 10, 2020

Citation: Larissa Montalvão Vieira, Josimar Gurgel Fernandes, Patrícia Ribeiro Santos, Sergio Carvalho de Paiva, Galba Maria de Campos Takaki, Arminda Saconi Messias. Evaluation of Coffee Sludge as an Adsorbent of Cations and Chlorides from Mangrove Sediments. Biomed J Sci \& Tech Res 30(2)2020. BJSTR. MS.ID.004927.
\end{abstract}

Keywords: Biosorbent; Sediment; Alternative Waste; Desalination Waste

\section{ABSTRACT}

The sludge is a residue from the processing of soluble coffee and represents, on average, $48 \%$ of the amount of green coffee used in the process. The high volumes of this waste reflect environmental problems for industries. This research aimed to study the use of coffee grounds with a view to the adsorption of chemical elements from the mangrove sediment irrigated with desalination waste. Under laboratory conditions, an experiment was carried out with PVC tubes, where $1.5 \mathrm{~kg}$ of mangrove sediment was added. Soon after, $300 \mathrm{~g}$ of coffee grounds was applied to the surface and also incorporated into the sediment, with irrigation with desalinator waste twice a week. The extract was collected every 15 days until 60 days, where $\mathrm{Na}^{+}, \mathrm{K}^{+}, \mathrm{Ca}^{2+}, \mathrm{Mg}^{2+}$ and $\mathrm{Cl}^{-}$were determined in each collection, with an indication that at 15 days of contact of the coffee sludge incorporated in the mangrove sediment, it presents a greater adsorption of the determined elements sodium $(3285.0 \mathrm{mg} / \mathrm{l})$, calcium $(282.0 \mathrm{mg} / \mathrm{l})$, magnesium $(316.0 \mathrm{mg} / \mathrm{l})$, chloride (3731.0mg/l); and potassium (24.0mg/l) at 30 days of contact.

\section{Introduction}

Mangroves are heterogeneous habitats with an unusual variety of animals and plants adapted to anaerobic conditions, highly saline and often flooded $[1,2]$. They are rich in nutrients, due to the existence of the deposition of roots and plant material and of decomposition, mainly by anaerobic bacteria that colonize sediments with low levels of oxygen [3, 4]. This biome is extremely important for the environmental balance and for the maintenance of marine life, as it houses a great biodiversity and consists of a natural nursery for several species $[5,6]$. The mangrove is characterized as part of a coastal zone and has great environmental importance for the fauna and flora of the region. The high primary activity due to the large amount of organic matter found allows the presence of fish, crustaceans, mollusks, reptiles, mammals, and nesting birds. The mangrove is an environment rich in organic carbon, offering protection against coastal erosion. It also has a social and economic importance since fishing is considered the main source of income for the riverside population [7-9]. The mangrove which is the object of this study is located in the municipality of Rio Formoso, located in the physiographic region of the Southern Meridional of the state of Pernambuco, 92km from the capital Recife.

Part of its territory is included in an Environmental Protection Area - APA (State Decree No. 19,635, of March 13, 1997), called APA de Guadalupe, which is located in the southern portion of the southern coast of the state of Pernambuco, covering part of of the municipalities of Sirinhaém, Rio Formoso, Tamandaré and Barreiros [10]. The Formoso River is $12 \mathrm{~km}$ long and rises in the northwest portion of the municipality of the same name. Close to the mouth, located between the Guadalupe point and the Carneiros 
beach, it receives Ariquindá and its affluent União, two important components of its basin. Along its route it receives domestic waste and residues from the sugar agribusiness [11]. The salinization of waters in the Northeast of Brazil has been revealed as a phenomenon as worrying as low rainfall. After the water desalination process, part of the solutes that were obtained in the process produces a by-product, a wastewater called tailings, with a much higher salt concentration than the original brackish water and polluting power for the soil, fauna, and flora. In some places, the waste reaches $75 \%$ of the original volume and one of the environmental problems found in this process is the disposal site, since it can cause damage to the environment [12-14].

Sludge is a waste produced in large quantities in the soluble coffee industries, and represents an environmental problem, as it contains carbohydrates (cellulose, hemicellulose, sugars), some proteins and other compounds that represent a large organic load, and, consequently, demand a high oxygen content for its degradation, despite its high moisture content. In addition, the residue still contains caffeine, tannins, and polyphenols [15]. Various destinations have been proposed for this residue, including use as fertilizer, animal feed, burning, and even as a raw material for obtaining biodiesel and alcohol [16]. Due to its richness in several constituents, this residue began to be studied, being an organic matter with excellent physical-chemical characteristics that make it possible to be valued and characterized as a coffee by-product, with a lot of potential to be explored, including as an adsorbent. This work's objective was to evaluate the efficiency of adsorption of chemical elements of the mangrove sediment, using coffee sludge.

\section{Materials and Methods}

The experiment was conducted at the Analytical Chemistry Laboratory, on the 8th floor of Block D, at the Science and Technology Center of Catholic University of Pernambuco, Recife, Pernambuco, Brazil, with average temperature of $20^{\circ} \mathrm{C}$. Five subsamples of mangrove sediment were collected in the municipality of Rio Formoso, Pernambuco, at coordinates 8운'17'S and 350 $06^{\prime} 30.1^{\prime \prime} \mathrm{W}$, under the SIRGAS 2000 reference system, located in the mesolitoral region, with little water. These subsamples were mixed to form a composite sample, with the following characteristics: Apparent density $=1.05 \mathrm{~g} / \mathrm{cm}^{3}$; Real density $=2.49 \mathrm{~g} / \mathrm{cm}^{3}$; Degree of flocculation $=32 \%$; Texture class = clay loam; Natural clay = 25\%; Residual humidity $=2.75 \%$; Humidity $0,33 \mathrm{~atm}=56.80 \%$; Humidity $15 \mathrm{~atm}=28.14 \%$; Available water $=28.66 \%$; $\mathrm{pH}\left(\mathrm{H}_{2} \mathrm{O}\right)$ $=5.70 ; \mathrm{Ca}^{2+}=4.00 \mathrm{cmolc} / \mathrm{dm}^{3} ; \mathrm{Mg}^{2+}=1.10 \mathrm{cmolc} / \mathrm{dm}^{3} ; \mathrm{Na}+=0.34$ $\mathrm{cmolc} / \mathrm{dm}^{3} ; \mathrm{K}+=0.20 \mathrm{cmolc} / \mathrm{dm}^{3} ;$ Sum of Exchangeable Bases (S) $=5.60 \mathrm{cmolc} / \mathrm{dm}^{3}$; Cation Exchange Capacity (CEC) $=10.3 \mathrm{cmolc} /$ $\mathrm{dm}^{3}$; Base Saturation $(\mathrm{V})=55 \%$, according to the methodology of the Brazilian Agricultural Research Corporation. The desalinator reject for irrigation was obtained from the desalinator located in the municipality of Riacho das Almas, Pernambuco, Brazil.
The physicochemical analysis was performed at the Agronomic Institute of Pernambuco (IPA) Plant, Ration and Water Analysis Laboratory - LAPRA with the following characteristics: electrical conductivity $=11.541 \mu \mathrm{S} / \mathrm{cm}$ at $25^{\circ} \mathrm{C}, \mathrm{Ca}^{2+}=403.00 \mathrm{mg} / \mathrm{L}^{2} \mathrm{Mg}^{2+}=$ $393.09 \mathrm{mg} / \mathrm{L}, \mathrm{Na}^{+}=200.00 \mathrm{mg} / \mathrm{L} ; \mathrm{K}^{+}=40.00 \mathrm{mg} / \mathrm{L}, \mathrm{RAS}=23.67, \mathrm{pH}$ $=7.9$, classification for irrigation $=$ C4S4 (very high salinity water and high sodium concentration). The physicochemical analysis of coffee sludge was performed at the Agronomic Institute of Pernambuco (IPA) Plant, Ration and Water Analysis Laboratory LAPRA with the following characteristics: $\mathrm{pH}=5.62$; $\mathrm{Ca}^{2+}=47.13 \%$; $\mathrm{Mg}^{2+}=7.15 \% ; \mathrm{Na}^{+}=1.00 \% ; \mathrm{K}^{+}=1.76 \% ; \mathrm{Cl}^{-}=450.49 \% ; \mathrm{C}=90.53$; $\mathrm{N}=2.32 ; \mathrm{C} / \mathrm{N}$ ratio $=39.02$. For the installation of the experiment 12 PVC tubes with $25 \mathrm{~cm}$ height and $9.8 \mathrm{~cm}$ internal diameter were used, presenting at the base an opening connected to a $0.7 \mathrm{~cm}$ diameter flexible hose that allowed the percolating liquid to pass through the sediment to the collecting container. The tubes were filled with $1.5 \mathrm{~kg}$ of mangrove sediment, enough to obtain a $20 \mathrm{~cm}$ high column. Soon after, $300 \mathrm{~g}$ of coffee sludge was applied to the surface and incorporated into the sediment, with irrigation with the waste twice a week.

The percolate in each tube was collected in a $250 \mathrm{ml}$ conical flask, at intervals of 15 days, up to 60 days, with the elements $\mathrm{Na}^{+}$and $\mathrm{K}^{+}$ (flame emission spectrophotometry), $\mathrm{Ca}^{2+}$ and $\mathrm{Mg}^{2+}$ (complexation titrimetry) and $\mathrm{Cl}^{-}$(precipitation titrimetry - Mohr method) being determined, for later statistical analysis, using Minitab 19 software.

\section{Results and Discussion}

The results obtained for the determination of $\mathrm{Na}^{+}, \mathrm{K}^{+}, \mathrm{Ca}^{2+}, \mathrm{Mg}^{2+}$ and $\mathrm{Cl}^{-}$are shown in (Figures 1 to 5). (Figure 1) shows the influence of the incorporated coffee sludge (IC) in the mangrove sediment for sodium adsorption (3285.0mg/l), up to 15 days of contact, with the highest leachate value when the coffee sludge was placed on the surface - SC $(7633.0 \mathrm{mg} / \mathrm{l})$, indicating less adsorption. When the coffee sludge on the surface - SC was in contact for 30 days (2590.0mg/l), 45 days $(2397.0 \mathrm{mg} / \mathrm{l})$ and 60 days $(2400.0 \mathrm{mg} / \mathrm{l})$ it was more promising in the sodium adsorption reaction in the sediment of mangrove. According to [17] it has been found through laboratory tests that seeds with crushed or ground Moringa husks are equally effective at adsorbing sodium from $1,868.0 \mathrm{mg} / \mathrm{l}$ to $24.6 \mathrm{mg} / \mathrm{l}$ (98.7\%). [18]'s experiment indicates that there is a tendency for sodium adsorption in the mangrove sediment with the crushed seed of Moringa oleifera with husks, after 30 days of contact, namely: $\mathrm{Na}^{+}$in the percolate at 30 days (MS = $3,620.0 \mathrm{mg} / \mathrm{l} ; \mathrm{MI}=3,246.7 \mathrm{mg} / \mathrm{l}$ ), $\mathrm{Na}^{+}$in the percolate at 45 days (MS $=2,746.7 \mathrm{mg} / \mathrm{l} ; \mathrm{MI}=2,880.0 \mathrm{mg} / \mathrm{l})$, and $\mathrm{Na}^{+}$in the percolate at 60 days ( $\mathrm{MS}=2,533.3 \mathrm{mg} / \mathrm{l}$; $\mathrm{MI}=2,410.0 \mathrm{mg} / \mathrm{l}$ ). Observing (Figure 2), potassium showed greater adsorption when coffee grounds were incorporated into the mangrove sediment, with 30 days of contact (24.0 mg/l). 


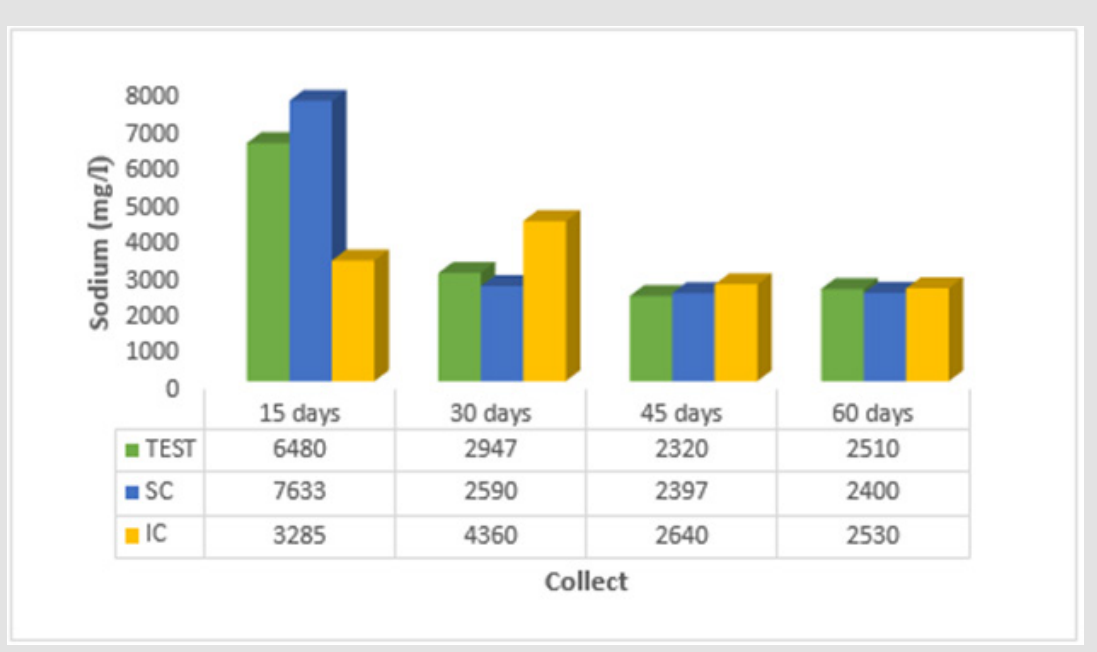

Figure 1:Average sodium $\left(\mathrm{Na}^{+}\right)$values of percolate collected at 15, 30, 45 and 60 days for the control (TEST), coffee sludge on the surface (SC) and incorporated (IC) into the mangrove sediment.

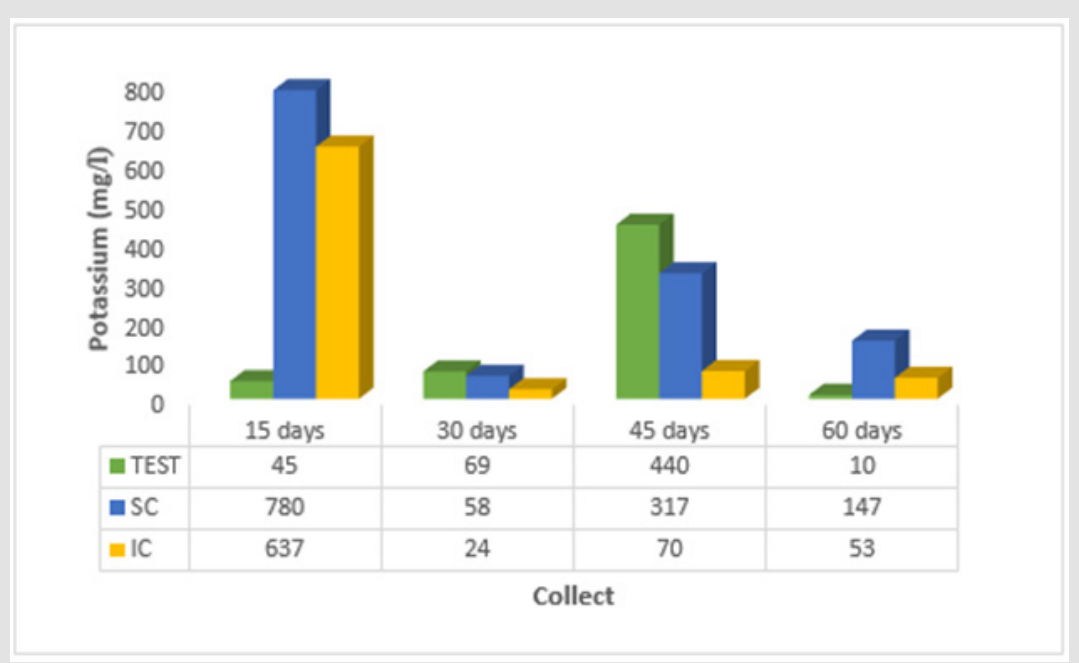

Figure 2: Average values of potassium $\left(\mathrm{K}^{+}\right)$of percolate collected at 15, 30, 45 and 60 days for the control (TEST), coffee sludge on the surface (SC) and incorporated (IC) into the mangrove sediment.

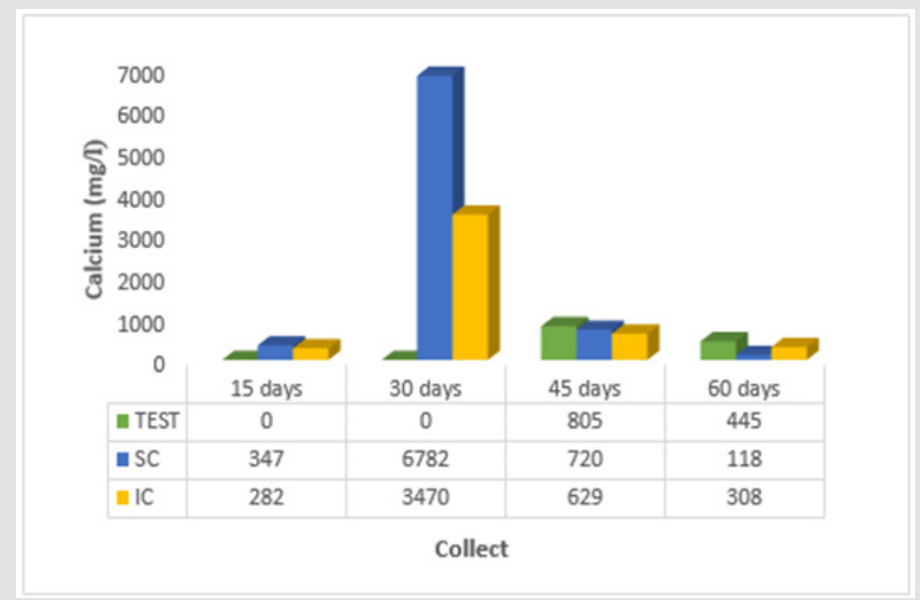

Figure 3: Average values of calcium $\left(\mathrm{Ca}^{2+}\right)$ of percolate collected at 15, 30, 45 and 60 days for the control (TEST), coffee sludge on the surface (SC) and incorporated (IC) in the mangrove sediment. the surface (SC) and incorporated (IC) into the mangrove sediment. 
Figure 4: Average magnesium values $\left(\mathrm{Mg}^{2+}\right)$ of the percolate collected at 15, 30, 45 and 60 days for the control (TEST), coffee sludge on the surface (SC) and incorporated (IC) into the mangrove sediment.

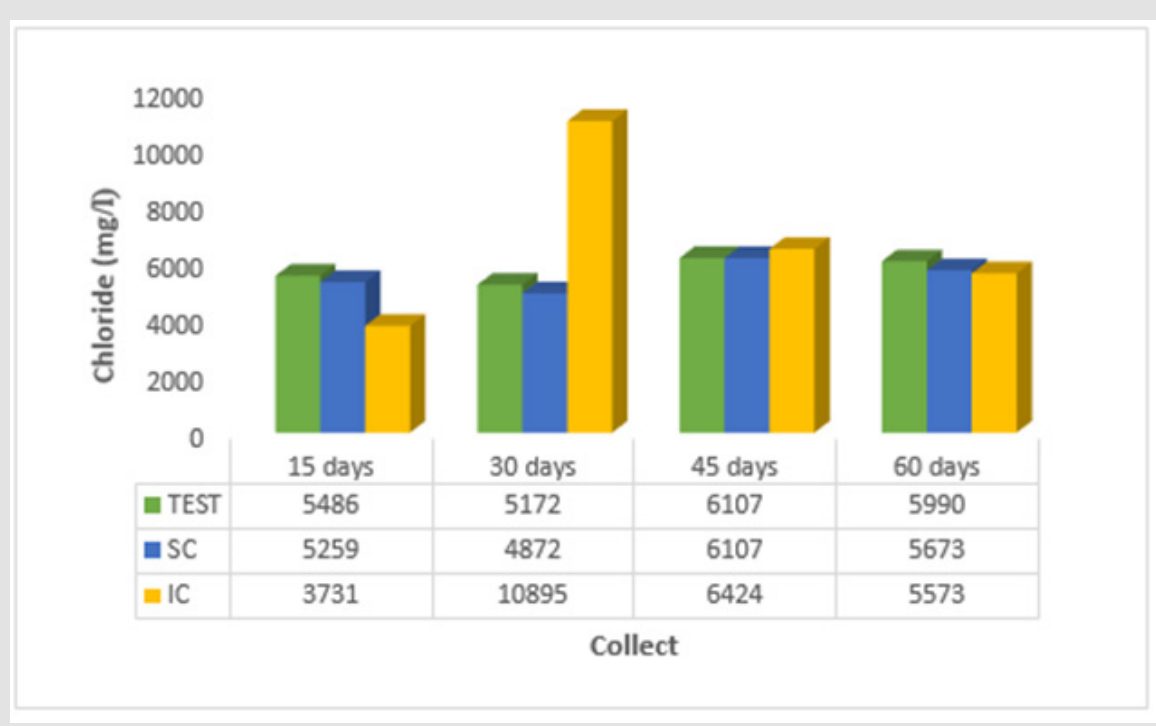

Figure 5: Average values of chloride $\left(\mathrm{Cl}^{-}\right)$of percolate collected at 15, 30, 45 and 60 days for the control (TEST), coffee sludge on the surface (SC) and incorporated (IC) into the mangrove sediment.

The analyzes related to the potassium adsorption process [19] obtained results distributed in two blocks: the first, with a slight adsorption in T1 (sediment after eight days of contact with the residues), despite being below the values found for T0 (control) for all treatments $(1=75 \mathrm{~S} 25 \mathrm{~B} ; 2=50 \mathrm{~S} 50 \mathrm{~B} ; 3=25 \mathrm{~S} 75 \mathrm{~B} ; 4=75 \mathrm{~S} 25 \mathrm{C} ; 5$ $=50 \mathrm{~S} 50 \mathrm{C} ; 6$ = 25S75C; 7 = 75S25CB; $8=50 \mathrm{~S} 50 \mathrm{CB} ; 9=25 \mathrm{~S} 75 \mathrm{CB}$; $10=75$ S25CA; 11 = 50S50CA; 12 = 25S75CA; 13 = 75S25A; $14=$ $50 \mathrm{~S} 50 \mathrm{~A} ; 15=25 \mathrm{~S} 75 \mathrm{~A}$ ); then, the second block where six treatments $(1=75 \mathrm{~S} 25 \mathrm{~B} ; 2$ = 50S50B; 3 = 25S75B; 7 = 75S25CB; 8 = 50S50CB; $9=25 \mathrm{~S} 75 \mathrm{CB}$ ) showed significant potassium adsorption at time T2 (sediment after 15 days of contact with the residues) indicating the fraction of the baroness/water hyacinth present and above the $\mathrm{T} 0$ values (control). The values obtained for calcium presented in
(Figure 3) show that already at 15 days of contact with the coffee grounds incorporated into the mangrove sediment, they indicated less leaching and consequent adsorption of this element (282.0 $\mathrm{mg} / \mathrm{l})$. Through laboratory tests [17] realized that the seeds with crushed or ground Moringa oleifera bark are equally effective in adsorption of calcium from $1.005 .0 \mathrm{mg} / \mathrm{l}$ to $894.6 \mathrm{mg} / \mathrm{l}$ (11\%), with 60 minutes of contact with desalinator reject.

The percolated calcium in the survey by [18] showed lower values at 15 days $(214.7 \mathrm{mg} / \mathrm{l}), 45$ days $(128.2 \mathrm{mg} / \mathrm{l})$ and 60 days $(114.8 \mathrm{mg} / \mathrm{l})$ when the moringa seed incorporated into the mangrove sediment was used. At 30 days, $\mathrm{Ca}^{2+}$ showed a value equal to $171.5 \mathrm{mg} / \mathrm{l}$ when the moringa was placed on the surface of the 
mangrove sediment, indicating increasing calcium absorption. In (Figure 4), it can be seen that magnesium was adsorbed in greater quantity when the leachate showed lower value (316.0 mg/l) at 15 days, with coffee sludge incorporated in the mangrove sediment. A study carried out by [20] reached the same result: the researcher proved that the powder of Moringa oleifera seeds in contact with the organic material of the well water reduces the hardness value in the period of 24 hours. Chloride presented, at 15 days of contact with coffee sludge incorporated into the mangrove sediment, less value in the leachate (3731 $\mathrm{mg} / \mathrm{l})$, which indicates greater adsorption of this ion. According to [12] it has been found through laboratory tests that seeds with crushed or ground Moringa husks are equally effective at adsorbing chloride from $6.997 .5 \mathrm{mg} / \mathrm{l}$ to $6.782 .4 \mathrm{mg} / \mathrm{l}(1.8 \%)$.

\section{Conclusion}

In view of the results obtained, it can be inferred that there is a tendency to recommend coffee sludge when incorporated into mangrove sediment, as it favors the adsorption of ions, since they presented the lowest values in the percolate at 15 days of contact: sodium (3285.0mg/l), calcium $(282.0 \mathrm{mg} / \mathrm{l})$, magnesium (316.0mg/l), chloride (3731. $0 \mathrm{mg} / \mathrm{l})$; and at 30 days of contact, potassium $(24.0 \mathrm{mg} / \mathrm{l})$.

\section{Acknowledgement}

The authors are grateful to the Foundation for the Support of Science and Technology of the State of Pernambuco (FACEPE) for the research aid, to the Consortium Universitas for the research aid and to the Analytical Chemistry Laboratory of Catholic University of Pernambuco for the support in the experiments.

\section{Conflicts of Interest}

The authors declare that there are no conflicts of interest.

\section{References}

1. Kulkarni R, Deobagkar D, Zinjarde S (2018) Metals in mangrove ecosystems and associated biota: A global perspective. Ecotoxicology and Environmental Safety 153(1): 215-228.

2. Tiralerdpanich P, Sonthiphand P (2018) Potential microbial consortium involved in the biodegradation of diesel, hexadecane and phenanthrene in mangrove sediment explored by metagenomics analysis. Marine Pollution Bulletin 133(1): 595-605.

3. Santos NCP (2019a) Black mangrove (Avicennia schaueriana) in phytoremediation of polycyclic aromatic hydrocarbons in mangrove sediment contaminated by oil.

4. Vaezzadeha V, Zakaria MP, Shau Hwaic AT, Ibrahimd ZZ, Mustafa S, et al. (2015) Forensic investigation of aliphatic hydrocarbons in the sediments from selected mangrove ecosystems in the west coast of Peninsular Malaysia. Marine Pollution Bulletin 100(1): 311-320.
5. Oliveira LML (2019) Influence of nutrients on the biodegradation of total petroleum hydrocarbons (HTP) dispersed by the formation of MPS oil aggregates (OSAS).

6. Rosario RPG, Abuchahla GMO (2018) Legal framework for mangrove protection. In: Fumi M (Edt.). Atlas of mangroves in Brazil. Brasilia: ICMBIO: pp. 75-84.

7. Santos LGGV (2019b) Evaluation of the contribution and distribution of organic matter in superficial sediments of the São Francisco River estuary using lipid biomarkers. Saint Cristopher. Dissertation (master's in chemistry). Federal University of Sergipe: p. 138.

8. Patwory R, Patwory K, Kalita MC, Deka S (2018) Application of biosurfactant for enhancement of bioremediation process of crude oil contaminated soil. International Biodeterioration \& Biodegradation 129: 50-60.

9. (2014) NOAA. National Oceanic and Atmospheric Administration. Oil Spills in Mangroves: planning \& response considerations: 2014. Washington, DC, USA.

10. (1998) Companhia Pernambucana do Meio Ambiente (CPRH) Management plan, coastal Economic Ecological Zoning - ZEEC de Guadalupe Litoral Sul de Pernambuco.

11. (1999) Companhia Pernambucana do Meio Ambiente (CPRH) Socioenvironmental diagnosis and ZEEC - Ecological Economic Zoning Coastal South coast of Pernambuco.

12. Gomes Filho AJ, Paiva SC, Takaki GMC, Messias AS (2019) Application of moringa in the removal of salts from the desalinator reject. Current Journal of Applied Science and Technology 36(1): 1-13.

13. Lima SSA, Paiva SC, Figueiredo HT, Takaki GMC, Messias AS (2019) Saline waters treatment using activated carbon filled filter. Current Journal of Applied Science and Technology 37(5): 1-7.

14. Djaman K, Balde AB, Sow A, Muller B, Irmak S, et al. (2015) Evaluation of sixteen reference evapotranspiration methods under sahelian conditions in the Senegal River Valley. Journal of Hydrology: Regional Studies 3(1): 139-159.

15. Boligon J (2015) Production and characterization of activated carbon from soluble coffee grounds.

16. Lamas CFS (2019) Study of the enzymatic hydrolysis of carbohydrates from coffee grounds with a view to the production of bioethanol. Higher Engineering Institute of Porto. Master (Chemical Engineering - Energy and Biorefinery): p. 57.

17. Gomes Filho AJ, Paiva SC, Takaki GMC, Messias AS (2019) Application of moringa in the removal of salts from the desalinator reject. Current Journal of Applied Science and Technology 36(1): 1-13.

18. Vieira LM, Silva AC, Almeida Neto JCB, Paiva SC, Takaki GMC, et al. (2020) Use of Moringa oleifera for adsorption of chemical elements from the mangrove sediment. International Journal of Research Studies in Science, Engineering and Technology 7(5): 1-7.

19. Lemos DGL, Silva Filho AAP, Barreto GCM, Batista CM, Paiva SC, et al. (2020) Use of alternative residues for adsorption of chemical elements from river sediment. International Journal of Research Studies in Science, Engineering and Technology 7(5): 1-12.

20. Mangale SM, Chonde SG, Raut PD (2012) Use of Moringa oleifera (drumstick) seed as natural absorbent and an antimicrobial agent for ground water treatment. Research Journal of Recent Sciences 1(3): 3140. 
ISSN: 2574-1241

DOI: 10.26717/BJSTR.2020.30.004927

Arminda Saconi Messias. Biomed J Sci \& Tech Res

(C) This work is licensed under Creative

Submission Link: https://biomedres.us/submit-manuscript.php

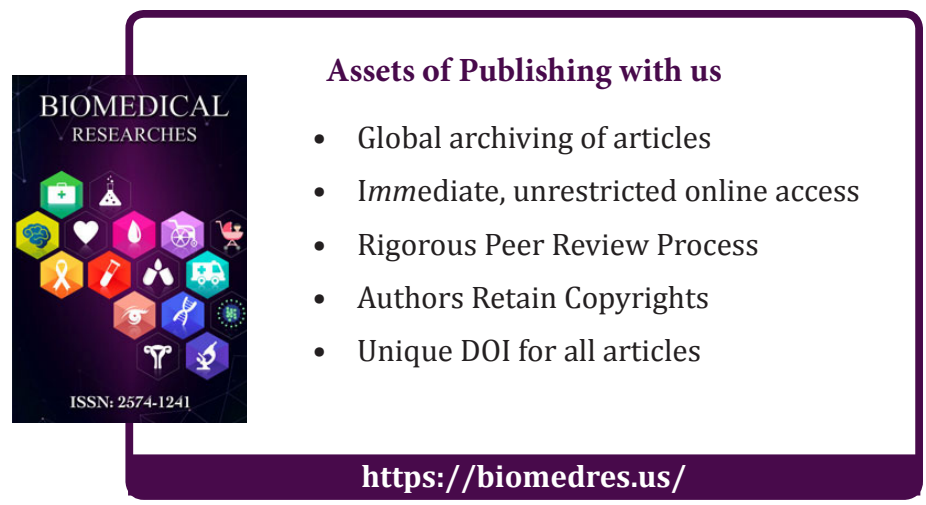

